\title{
DUODÉCIMO DO LEGISLATIVO MUNICIPAL: DA IMPOSSIBILIDADE DE CONTABILIZAÇÃO DO PRODUTO DA ARRECADAÇÃO DA PRESTAÇÃO DE SERVIÇO PÚBLICO DE SANEAMENTO BÁSICO PARA SUA FORMAÇÃO
}

Leonardo Vasconcellos Braz Galvão*

David Maia Bezerra**

Resumo: O presente trabalho tem como escopo analisar a natureza jurídica do produto da arrecadação (contraprestação) proveniente da prestação do serviço público municipal de saneamento básico (abastecimento de água e coleta de esgotos) e sua classificação orçamentária, demonstrando-se a inviabilidade de contabilizar tal receita como receita tributária apta a compor o valor do repasse (duodécimo) devido às Câmaras de Vereadores.

Palavras-Chave: Poder Legislativo - Orçamento Público - Saneamento Básico - Arrecadação Receita Tributária - Tarifa - Duodécimo.

Abstract: This work has the objective to analyze the legal nature of the storage product (consideration) from the provision of municipal public service of sanitation (water supply and sewage) and its budget classification, demonstrating the impossibility of accounting for such revenue as tax revenue able to compose the value of the transfer (twelfth) due to the City Councils.

Keywords: Legislature - Public Budget - Sanitation - Storage - Tax Revenue - Rate - Twelfth

\footnotetext{
* Mestrando em Direito do Estado (Administrativo) pela PUC-SP

** Mestrando em Direito do Estado (Tributário) pela PUC-SP

http://revistasapereaude.org/index.php/edicoes/ano-5-volume-3-outubro-2016 


\section{Introdução}

O manuseio de recursos públicos é sempre uma questão relevante em qualquer ordenamento jurídico, possuindo relevo assaz proeminente em uma República democrática, como se define o Brasil.

Neste cenário é que o presente artigo tenta se situar, buscando o fomento da discussão acadêmica em torno da indagação jurídica pertinente à natureza jurídica dos valores arrecadados pelas concessionárias públicas municipais (autarquias ou empresas) brasileiras prestadoras de serviço público de saneamento básico, com a definição dada pela Lei Federal n. ${ }^{\circ}$ $11.445 / 07$

À primeira vista o tema pode parecer de somenos importância, todavia, uma compreensão sistêmica do mesmo nos fará perceber que esta definição tem consequências práticas importantes, notadamente no campo das finanças públicas, já que, a depender da classificação jurídica que se adote, pode-se concluir que o produto da arrecadação decorrente da prestação deste serviço público por intermédio de concessionária pública municipal, compõe, ou não, as receitas

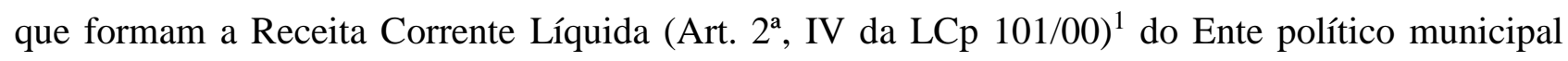

\footnotetext{
${ }^{1}$ Art. 2o Para os efeitos desta Lei Complementar, entende-se como:

I - omissis;

II - omissis;

III - omissis;

IV - receita corrente líquida: somatório das receitas tributárias, de contribuições, patrimoniais, industriais, agropecuárias, de serviços, transferências correntes e outras receitas também correntes, deduzidos:
}

a) na União, os valores transferidos aos Estados e Municípios por determinação constitucional ou legal, e as contribuições mencionadas na alínea a do inciso I e no inciso II do art. 195, e no art. 239 da Constituição;

b) nos Estados, as parcelas entregues aos Municípios por determinação constitucional; 
instituidor ou controlador da concessionária, impactando, assim, entre outras coisas, no cálculo do duodécimo que deve ser repassado ao Poder Legislativo local (Art. 168 da CRFB). ${ }^{2}$

O aspecto controvertido acima anunciado, restrito ao âmbito dos Municípios, é o objeto de investigação deste artigo, cujas premissas e conclusões logo passamos a desenvolver.

\section{Do Saneamento Básico. Conceito Preliminar}

Antes da análise jurídica que se propõe, se faz necessário adotar algumas definições preliminares sobre o próprio conceito de saneamento básico, dês que é instituto proveniente da engenharia, e que na época da promulgação da Constituição da República vigente ainda não estava legalmente definido, tal lacuna somente veio ser suprida quase 20 (vinte) anos após a promulgação da Carta Magna, com o advento da Lei Federal n. ${ }^{\circ}$ 11.445/2007 (Lei Nacional, no sentido da clássica lição de Geraldo Ataliba $^{3}$ ).

Nesse sentido, para fins deste escrito, tomaremos por base a definição positivada por intermédio da Lei Nacional atinente à espécie, a qual, em seu art. $3^{\circ}$, define saneamento básico como o "conjunto de serviços, infraestruturas e instalações operacionais de (a) abastecimento de água potável; b) esgotamento sanitário; c) limpeza urbana e manejo de resíduos sólidos e d) drenagem e manejo das águas pluviais urbanas". ${ }^{4}$

c) na União, nos Estados e nos Municípios, a contribuição dos servidores para o custeio do seu sistema de previdência e assistência social e as receitas provenientes da compensação financeira citada no $\$ 9^{\circ}$ do art. 201 da Constituição.

${ }^{2}$ Art. 168. Os recursos correspondentes às dotações orçamentárias, compreendidos os créditos suplementares e especiais, destinados aos órgãos dos Poderes Legislativo e Judiciário, do Ministério Público e da Defensoria Pública, ser-lhes-ão entregues até o dia 20 de cada mês, em duodécimos, na forma da lei complementar a que se refere o art. 165, $\S 9^{\circ}$. (Redação dada pela Emenda Constitucional $n^{\circ} 45$, de 2004)

${ }^{3}$ ATALIBA Geraldo. Regime constitucional e leis nacionais e federais. Revista de Direito Público. Ano XIII, nº 5354, pp. 58-75, Jan./Jun. 1980.

${ }^{4}$ Art. 3o Para os efeitos desta Lei, considera-se:

I - saneamento básico: conjunto de serviços, infra-estruturas e instalações operacionais de:

http://revistasapereaude.org/index.php/edicoes/ano-5-volume-3-outubro-2016 
Merece menção, apenas para fins ilustrativos, que o conceito empregado pela Organização Mundial de Saúde (OMS), para precisar o saneamento é bem mais amplo, posto que o conceitua como "o controle de todos os fatores do meio físico do homem, que exercem ou podem exercer efeitos nocivos sobre o bem-estar físico, mental e social".

Dessa forma, claro está que o saneamento básico é um instrumento capaz de melhorar a qualidade de vida das pessoas, melhorando-lhes a saúde; investimento que racionaliza as despesas públicas, dado que importa em economia das despesas com tratamentos de saúde curativa e ainda contribui para a própria ideia de continuidade da vida humana na Terra, visto que preserva os recursos naturais indispensáveis à sobrevivência da nossa espécie.

Neste contexto, dado o inegável interesse público incidente sobre a matéria, é que a própria norma fundamental fundante de nossa República tratou do assunto nominalmente, ex vi do seu art. 23, IX, daí porque, na passagem precedente, justifica dizer que é competência legislativa concorrente dos entes políticos dispor sobre a matéria, razão da Lei nacional sobre a matéria.

\section{Da titularidade do serviço de saneamento básico}

Ainda que por ocasião da promulgação da Constituição Federal em vigor, no Brasil, não houvesse definição normativa para o saneamento básico, dedicou a nossa Lex Mater diversos dispositivos explícitos ao tema em comento.

a) abastecimento de água potável: constituído pelas atividades, infra-estruturas e instalações necessárias ao abastecimento público de água potável, desde a captação até as ligações prediais e respectivos instrumentos de medição;

b) esgotamento sanitário: constituído pelas atividades, infra-estruturas e instalações operacionais de coleta, transporte, tratamento e disposição final adequados dos esgotos sanitários, desde as ligações prediais até o seu lançamento final no meio ambiente;

c) limpeza urbana e manejo de resíduos sólidos: conjunto de atividades, infra-estruturas e instalações operacionais de coleta, transporte, transbordo, tratamento e destino final do lixo doméstico e do lixo originário da varrição e limpeza de logradouros e vias públicas;

d) drenagem e manejo das águas pluviais urbanas: conjunto de atividades, infra-estruturas e instalações operacionais de drenagem urbana de águas pluviais, de transporte, detenção ou retenção para o amortecimento de vazões de cheias, tratamento e disposição final das águas pluviais drenadas nas áreas urbanas. (sic). 
Despiciendo rememorar que nossa Norma fundamental, ao estabelecer a Federação como forma de Estado (art. $1^{\circ}$ ), impôs como consequência do modelo duas linhas mestras: a ideia de autonomia dos Entes e a divisão de suas competências, com um sistema de repartição vertical e espacial de poderes, competência esta que assume 3 facetas básicas (i) políticoadministrativas, (ii) legislativas e (iii) tributárias, podendo ser exercidas de forma individual ou coletivamente, conforme o regramento previsto na própria Constituição, que estabelece hipóteses de competências exclusivas, comuns e concorrentes.

Neste tópico ficaremos restritos à análise da competência político-administrativa em matéria de saneamento básico.

Mais que uma competência, o trato dessa matéria se afigura, em nosso sentir, como um dever-poder, dado o caráter de função (atividade de quem não é dono como asseverado por Rui Cirne Lima), que informa todo o agir administrativo consoante a sempre atual lição do eminente Prof. Celso Antônio Bandeira de Mello. ${ }^{5}$

Parece-nos evidente que a obrigação que o Estado, em sentido lato, e seus mandatários e servidores têm de perseguir à exaustão a consecução do interesse público, exime de qualquer dúvida o intérprete quanto ao dever de mútua cooperação entre os 3 (três) Entes federativos, cooperação esta que, em nossa opinião, permeia todo o sistema e que deve ser a premissa principal (maior) a nortear qualquer interpretação que se faça quanto à disciplina jurídica do saneamento básico no Brasil.

A percepção deste verdadeiro postulado (mútua cooperação) não é resultado do livre subjetivismo do intérprete, mas consequência lógica da ratio legis inspiradora do Constituinte originário que estabeleceu ser de competência comum da União, dos Estados-membro, Distrito

\footnotetext{
5 BANDEIRA DE MELlo, Celso Antônio. Curso de Direito Administrativo. 31. ed. São Paulo: Malheiros, $2014, p$. 100.
} 
Federal e dos Municípios a promoção de programas de construção de moradias e a melhoria das condições habitacionais e de saneamento básico, nos exatos termos do art. 23, IX, ${ }^{6}$ da vigente Carta Política.

Ainda que não houvesse expressa menção ao saneamento básico na norma constitucional, conforme alhures citado, poderíamos extrair a sua igualmente disciplina constitucional dos comandos sobre (i) Saúde Pública e (ii) Controle da Poluição e Preservação do Meio Ambiente, ambas igualmente tratadas como competências comuns (ou concorrentes) no exato dizer do mesmo art. 23, II e VI, respectivamente, do texto inaugural de nossa República.

Embora ainda não exista(m) em nosso ordenamento a(s) Lei(s) Complementar(es) prevista(s) no parágrafo único do citado art. $23,{ }^{7}$ não nos parece razoável sustentar que a ausência da Lei desincumba os Entes federativos de cumprir com seu mister (competências), relativo à implementação das ações de saneamento básico, especialmente por ser a atuação administrativa vinculada à ideia de função (preceito obrigatório), como antes já abordado.

As competências comuns estabelecidas no art. 23 da CF/88 são corolários do nosso modelo federalista, cuja matriz constitucional claramente optou por ser um federalismo cooperativo, em detrimento de um modelo de federação dual (igualitária) de inspiração ianque.

Reforçando esse aspecto da cooperação, não se pode olvidar também a disciplina do art. 241 da Constituição, expressa no sentido de determinar que "a União, os Estados, o Distrito Federal e os Municípios disciplinarão por meio de lei os consórcios públicos e os convênios de cooperação entre os entes federados, autorizando a gestão associada de serviços públicos, bem

6 Art. 23. É competência comum da União, dos Estados, do Distrito Federal e dos Municípios: (...)

IX - promover programas de construção de moradias e a melhoria das condições habitacionais e de saneamento básico.

(...)

7 Parágrafo único. Leis complementares fixarão normas para a cooperação entre a União e os Estados, o Distrito Federal e os Municípios, tendo em vista o equilíbrio do desenvolvimento e do bem-estar em âmbito nacional. 
como a transferência total ou parcial de encargos, serviços, pessoal e bens essenciais à continuidade dos serviços transferidos”.

Cientes da obrigatoriedade que a Administração Pública tem em implementar o saneamento básico e calcados na premissa da necessária cooperação mútua entre os 3 (três) Entes Políticos, visto que se trata de competência comum entre estes, devemos aprofundar na análise dos papéis desses Entes na materialização das ações governamentais voltadas à concretização desse ditame constitucional.

O comando constitucional relacionado com a titularidade de prestação do serviço de saneamento, mesmo que indiretamente, é o do art. $30, \mathrm{~V},{ }^{8}$ que estabelece cláusula genérica pela qual compete ao Município prestar serviços de interesse local.

Como se pode observar, o citado dispositivo consagra a ideia de subsidiariedade, pelo qual todos os serviços de interesse tipicamente local, isto é, que possam ser prestados adequadamente pelo Município, direta ou indiretamente, e se relacionem com a sua realidade de forma específica, estejam no âmbito de competência desse Ente federativo.

Resta, todavia, definir o que é interesse local. A rigor, praticamente todo e qualquer serviço apresentará, em última instância, uma dose de interesse local, ao passo que dificilmente algum serviço local será indiferente aos interesses regionais e mesmo nacionais.

Basta imaginar o serviço de telefonia, de produção de energia elétrica e de distribuição de gás canalizado, os dois primeiros conferidos à União (art. 21, XI e XII, b) e o último

\footnotetext{
8 Art. 30. Compete aos Municípios:

(...)

$V$ - organizar e prestar, diretamente ou sob regime de concessão ou permissão, os serviços públicos de interesse local, incluído o de transporte coletivo, que tem caráter essencial.
}

http://revistasapereaude.org/index.php/edicoes/ano-5-volume-3-outubro-2016

D.O.I: $10.20523 /$ sapereaude-ano5-vol-3-pg-99-120 
aos Estados (art. 25, $\left.\S 2^{\circ}\right)^{9}$. Todos esses serviços repercutem sobre os Municípios e seus habitantes que, por óbvio, desenvolvem os mais diversos interesses (sentido comum) acerca deles. Mesmo assim, a própria Carta estatuiu que tais serviços não serão de titularidade dos Municípios, visto que atribuídos a outros Entes federativos de forma expressa.

Aos Estados compete tratar concorrentemente da proteção ambiental e controle de poluição, na forma como dispõem os parágrafos do art. 24. Os Municípios não mereceram qualquer menção específica nessa distribuição, salvo que remanesce, em todo tempo, sua competência geral para suplementar a legislação federal e a estadual no que couber, como lhe autoriza o art. 30, II, da Carta de 1988.

Destarte, todo o serviço público que não esteja expressamente afetado a outro ente federativo e que possa ser caracterizado como de predominante interesse local, relativamente ao interesse dos Estados e da União, será da competência dos Municípios. A regra vale, naturalmente, para os serviços dedicados ao saneamento básico.

Merece registro que no labor do intérprete para definir o conceito de interesse local, deve ser utilizado o critério da predominância dos interesses, já que há, quase sempre, uma nítida superposição dos interesses das populações, derivadas do fato de que a população municipal faz parte da população estadual, que por sua vez compõe a população da União. A grande missão do intérprete é fazer a distinção, caso a caso, de qual interesse será predominante em determinada situação para, assim, conseguir estabelecer qual competência político-administrativa será exercida, com escopo de identificar qual ente é o seu titular.

\footnotetext{
${ }^{9}$ Art. 25. Os Estados organizam-se e regem-se pelas Constituições e leis que adotarem, observados os princípios desta Constituição.

$\S 1^{\circ}$ São reservadas aos Estados as competências que não lhes sejam vedadas por esta Constituição.

$\S 2^{\circ}$ Cabe aos Estados explorar diretamente, ou mediante concessão, os serviços locais de Gás canalizado, na forma da lei, vedada a edição de medida provisória para a sua regulamentação.

http://revistasapereaude.org/index.php/edicoes/ano-5-volume-3-outubro-2016 
Em percuciente artigo publicado pela revista da Procuradoria Geral do Município de Belo Horizonte/MG, o Professor Maurício Zockun enfrenta com profundidade esta questão trazendo lúcida conclusão, vejamos:

“ (...) Eis a essência da finalidade da competência legislativa municipal que autoriza a edição de lei versando sobre tema de interesse local: solucionar tema que se revela peculiar àquela localidade a ensejar, justamente em razão disso, solução que acolha como pressuposto esta peculiaridade.

Por esta razão, não há, no plano formal, conflito entre as competências legislativas estadual, federal, nacional e municipal, pois o objeto por elas disciplinado é distinto. Vale dizer: cada uma delas pretende tutelar distintos bens jurídicos. $" 10$

Destarte, podemos concluir que, ressalvadas as regiões metropolitanas que tem interpretação distinta dada pelo Supremo Tribunal Federal em sede vinculativa de Ação Direta de Inconstitucionalidade, a prestação de serviços públicos de saneamento, dado o seu interesse eminentemente local, comunitário, é de titularidade dos Municípios, pela interpretação constitucional já mencionada.

\section{Da natureza jurídica da contraprestação dos serviços de saneamento básico}

A controvérsia reside justamente quanto a natureza jurídica dos valores arrecadados pelas empresas ou autarquias municipais decorrentes da contraprestação do serviço de fornecimento de águas e coleta de esgotos. Seriam estes valores taxas ou tarifas/preços públicos? A depender da resposta, pode haver repercussão na composição do duodécimo devido aos Legislativos municipais, na exata dicção do art. 29-A da Constituição Federal, vejamos:

${ }^{10}$ Zockun, Maurício Garcia Pallares. R. Proc.-Geral Mun. Belo Horizonte - RPGMBH, Belo Horizonte, ano 3, n. 5, p. 249-260, jan./jun. 2010.

http://revistasapereaude.org/index.php/edicoes/ano-5-volume-3-outubro-2016 D.O.I: $10.20523 /$ sapereaude-ano5-vol-3-pg-99-120 
Art. 29-A. O total da despesa do Poder Legislativo Municipal, incluídos os subsídios dos Vereadores e excluídos os gastos com inativos, não poderá ultrapassar os seguintes percentuais, relativos ao somatório da receita tributária e das transferências previstas no $\S 5^{\circ}$ do art. 153 e nos arts. 158 e 159 , efetivamente realizado no exercício anterior: (Incluído pela Emenda Constitucional no 25, de 2000)

Conforme visto, a delimitação do conceito de receita tributária é essencial para solução da controvérsia, especialmente se as receitas arrecadadas pelo prestador do serviço de abastecimento de água e coleta de esgotos têm natureza tributária.

Pois bem. O Código Tributário Nacional traz em seu art. $3^{\circ}$, o conceito legal de tributo:

“Art. $3^{\circ}$ Tributo é toda prestação pecuniária compulsória, em moeda ou cujo valor nela se possa exprimir, que não constitua sanção de ato ilícito, instituída em lei e cobrada mediante atividade administrativa plenamente vinculada."

À evidência, para uma dada exação se enquadrar no conceito de tributo acima mencionado, deve se amoldar a todos os enunciados nele contidos. E tal não ocorre em relação ao valor decorrente da remuneração da prestação dos serviços de água e esgoto prestados por concessionária ou mesmo por entidade autárquica. Vejamos.

É clássica a distinção entre taxa e preço público ou tarifa ${ }^{11}$. As $\operatorname{taxas}^{12}$

\footnotetext{
${ }^{11}$ Paulo de Barros Carvalho afirma que o uso já consagrou a equiparação dos termos "preço público" e "tarifa". Ressalve-se, somente, que "tarifa", na tradição do Direito Financeiro, significa a tabela de preços e

http://revistasapereaude.org/index.php/edicoes/ano-5-volume-3-outubro-2016 
são espécies de tributo, instituídas pelos entes de direito público interno (União, Estados, DF e Municípios), caracterizadas por apresentar, em sua hipótese normativa, a descrição de fato que evidencia certa ação estatal, específica e diretamente voltada ao contribuinte. Elas decorrem de uma prestação estatal dirigida ao contribuinte, sendo regidas pelo direito público.

De lado outro, o preço público, conforme Paulo de Barros Carvalho ${ }^{13}$, consiste "na remuneração decorrente da prestação de serviço de interesse público, ou do fornecimento ou locação de bens públicos, efetivada em regime contratual $e$ não imposta compulsoriamente às pessoas”.

Assim, o preço público ou tarifa remunera o serviço público prestado, sob regime de direito privado, por intermédio de empresas concessionárias. Em se analisando sob a ótica daquele a quem onera, consiste no valor pecuniário que os usuários devem pagar à empresa concessionária toda vez que fizerem uso do serviço prestado; vista sob o ângulo de quem desempenha, a tarifa é a remuneração que a empresa concessionária está legitimada a cobrar, dos usuários, em virtude dos serviços públicos efetivamente prestados.

A cobrança do preço público almeja, entre outras finalidades, garantir o custeio da prestação dos serviços concedidos; remunerar, de forma justa, o capital investido pelas concessionárias; e melhorar e expandir os serviços,

não os preços em si. (In Direito Tributário, linguagem e método. São Paulo: Noeses, 2009 - $3^{\mathrm{a}}$ edição. P. 404).

12 Art. 145, da CF: A União, os Estados, o Distrito Federal e os Municípios poderão instituir os seguintes tributos: (...) II - taxas, em razão do exercício do poder de polícia ou pela utilização, efetiva ou potencial, de serviços públicos específicos e divisíveis, prestados ao contribuinte ou postos à sua disposição.

Art. 77, do CTN: As taxas cobradas pela União, pelos Estados, pelo Distrito Federal ou pelos Municípios, no âmbito de suas respectivas atribuições, têm como fato gerador o exercício regular do poder de polícia, ou a utilização, efetiva ou potencial, de serviço público específico e divisível, prestado ao contribuinte ou posto à sua disposição.

${ }^{13}$ Direito Tributário, linguagem e método. São Paulo: Noeses, 2009 - $3^{\text {a }}$ edição

http://revistasapereaude.org/index.php/edicoes/ano-5-volume-3-outubro-2016

D.O.I: $10.20523 /$ sapereaude-ano5-vol-3-pg-99-120 
assegurando o equilíbrio econômico do contrato ${ }^{14}$.

Tanto na taxa quanto no preço público existe vantagem mensurável para o indivíduo. Entrementes, enquanto na taxa há a obrigatoriedade do serviço mensurável; no preço público ${ }^{15}$ o que existe é facultatividade dos serviços mensuráveis. Acrescente-se, nesse viés, que a taxa está jungida à atividade legislativa, isto é, conditio sine qua non para sua instituição é a edição de lei; já em se tratando de preço público não subsiste tal exigência.

Nessa linha, enquanto as taxas regem-se pelo regime jurídico de direito público, as tarifas estão circunscritas ao regime contratual privado, ou seja, o preço público visa remunerar o serviço público prestado, via de regra, por empresas concessionárias, sob regime de direito privado. Tarifa, portanto, não é tributo, é apenas uma contraprestação que decorre do consumo, pelas pessoas, de bens ou serviços públicos.

Finalizando as distinções entre taxa e tarifa, tem-se o seguinte: na taxa, o sujeito ativo é uma pessoa jurídica de direito público, ao passo em que no preço público pode ser tanto pessoa jurídica de direito público ou de direito privado; a taxa pode ser cobrada em virtude de utilização efetiva ou potencial de serviço público, já quanto ao preço público apenas haverá a sua cobrança se houver efetiva utilização do serviço; na taxa, a receita arrecadada é derivada, ao tempo em que na tarifa a receita é

\footnotetext{
${ }^{14}$ Neste sentido é a lição do Professor Paulo de Barros Carvalho, In Direito Tributário, linguagem e método. São Paulo: Noeses, $2009-3^{\mathrm{a}}$ edição

15 Veja-se a posição do então Ministro do STF Moreira Alves, acerca do preço público ("Taxa e preço público", in Caderno de Pesquisa Tributária n. 10, São Paulo, Resenha Tributária, 1985,p. 174): "Preço público é o preço contratual, que constitui contra-prestação de serviços de natureza comercial ou industrial - e que, por isso mesmo, podem ser objeto de concessão para particulares -, serviços esses prestados por meio de contrato de adesão. Para haver preço público é necessário existir contrato, ainda que tacitamente celebrado, e o contrato ainda que de adesão, dá a quem pretende celebrá-lo, se aderir às condições dele, a liberdade de não contratar, atendendo a sua necessidade por outro meio lícito. Quem não quiser tomar ônibus, e aderir, portanto, ao contrato de transporte, poderá ir, licitamente, por outros meios, ao lugar de destino. O que não tem sentido é pretender-se a existência de contrato quando o que deve aderir não tem sequer a liberdade de não contratar, porque, licitamente, não tem meio algum para obter o resultado de que necessita" (RTJ/ STF n. 98).
} 
originária; finalmente, em virtude de ser tributo, a taxa se sujeita aos princípios tributários (legalidade, anterioridade, noventena e outros), o que não se verifica com o preço público/tarifa.

Correlato à temática da distinção entre taxa e preço público, veja-se a expressão receita tributária, acerca da qual a Constituição Federal prescreve, no art. 29-A, o seguinte:

\begin{abstract}
Art. 29-A. O total da despesa do Poder Legislativo Municipal, incluídos os subsídios dos Vereadores e excluídos os gastos com inativos, não poderá ultrapassar os seguintes percentuais, relativos ao somatório da receita tributária e das transferências previstas no $\S 50$ do art. 153 e nos arts. 158 e 159, efetivamente realizado no exercício anterior: (...)
\end{abstract}

Nos termos do art. 175 da $\mathrm{CF} / 88^{16}$, cabe ao Poder Público, na forma da lei, diretamente ou sob regime de concessão ou permissão, sempre por meio de licitação, prestação de serviços públicos, devendo a lei dispor sobre a política tarifária.

Regulamentando tal dispositivo constitucional, a Lei Federal $\mathrm{n}^{\circ}$

\footnotetext{
${ }^{16}$ Art. 175. Incumbe ao Poder Público, na forma da lei, diretamente ou sob regime de concessão ou permissão, sempre através de licitação, a prestação de serviços públicos.

Parágrafo único. A lei disporá sobre:

I - o regime das empresas concessionárias e permissionárias de serviços públicos, o caráter especial de seu contrato e de sua prorrogação, bem como as condições de caducidade, fiscalização e rescisão da concessão ou permissão;

II - os direitos dos usuários;

III - política tarifária;

IV - a obrigação de manter serviço adequado.
}

http://revistasapereaude.org/index.php/edicoes/ano-5-volume-3-outubro-2016

D.O.I: 10.20523/sapereaude-ano5-vol-3-pg-99-120 
8.987/95, em seu art. $9^{\circ}$, e parágrafos, dispondo sobre a referida política tarifária, apregoa o seguinte:

“Art. 90 A tarifa do serviço público concedido será fixada pelo preço da proposta vencedora da licitação e preservada pelas regras de revisão previstas nesta Lei, no edital e no contrato.

$\S 1^{0}$ A tarifa não será subordinada à legislação específica anterior $e$ somente nos casos expressamente previstos em lei, sua cobrança poderá ser condicionada à existência de serviço público alternativo e gratuito para o usuário.

$\S 20$ Os contratos poderão prever mecanismos de revisão das tarifas, a fim de manter-se o equilíbrio econômico-financeiro.

$\S 30$ Ressalvados os impostos sobre a renda, a criação, alteração ou extinção de quaisquer tributos ou encargos legais, após a apresentação da proposta, quando comprovado seu impacto, implicará a revisão da tarifa, para mais ou para menos, conforme o caso.

$\S 40$ Em havendo alteração unilateral do contrato que afete o seu inicial equilíbrio econômico-financeiro, o poder concedente deverá restabelecê-lo, concomitantemente à alteração."

Imprescindível, neste ponto, observar o quanto prescrito pela Lei Federal $n^{\circ}$ 11.445/07, Diploma Normativo esse que traça as diretrizes nacionais para o saneamento básico, prescrevendo que, preferencialmente, os serviços de http://revistasapereaude.org/index.php/edicoes/ano-5-volume-3-outubro-2016 
abastecimento de água e esgotamento sanitário serão remunerados por meio de tarifas ou preços públicos. A propósito, veja-se redação do seu art. 29, I, litteris:

Art. 29. Os serviços públicos de saneamento básico terão a sustentabilidade econômico-financeira assegurada, sempre que possível, mediante remuneração pela cobrança dos serviços:

I - de abastecimento de água e esgotamento sanitário: preferencialmente na forma de tarifas e outros preços públicos, que poderão ser estabelecidos para cada um dos serviços ou para ambos conjuntamente;

\section{Conclusão}

Diante desse arcabouço normativo, a conclusão a que se chega é a de que a natureza jurídica do recolhimento financeiro proveniente da arrecadação cobrada por concessionária de serviço público ou por autarquia pública municipal que preste serviços de fornecimento de água e esgoto é a de preço público, não compondo, assim, a receita tributária prevista no art. 29-A, caput, da Constituição da República.

\section{É justamente nesse sentido que hoje está pacificada a}

jurisprudência dos Tribunais Superiores. No ano de 2010 a Primeira Seção do Superior Tribunal de Justiça (STJ), na esteira do que já havia sido decidido pelo STF relativo ao tema, enfrentou a questão nos autos do Recurso Especial n. ${ }^{\circ}$ 1.117.903-RS, julgado pela sistemática dos Recursos Repetitivos (Lei Federal n. ${ }^{\circ}$ 11.672/2008), consolidando o entendimento de que a contraprestação pelos serviços de água e esgoto não possui caráter tributário por ter natureza jurídica de tarifa ou preço público e que sua prescrição é regida pelo Código Civil. O recurso foi

http://revistasapereaude.org/index.php/edicoes/ano-5-volume-3-outubro-2016

D.O.I: $10.20523 /$ sapereaude-ano5-vol-3-pg-99-120 
julgado pelo rito da Lei dos Recursos Repetitivos (Lei n. 11.672/2008).

Citando vários precedentes do STJ e do Supremo Tribunal Federal (STF), o relator do processo, Ministro Luiz Fux, reiterou que a natureza jurídica da remuneração dos serviços de água e esgoto prestados por concessionária de serviço público é de tarifa ou preço público, consubstanciando em contraprestação de caráter não-tributário, razão pela qual não se submete ao regime jurídico tributário estabelecido para as taxas, verbis:

“PROCESSO CIVIL. RECURSO ESPECIAL REPRESENTATIVO DE CONTROVÉRSiA. ARTIGO 543-C, DO CPC. TRIBUTÁRIO. EXECUÇÃO FISCAL. CRÉDITO NÃO-TRIBUTÁRIO. FORNECIMENTO DE SERVIÇO DEÁGUA E ESGOTO. TARIFA/PREÇO PÚBLICO. PRAZO PRESCRICIONAL. CÓDIGO CIVIL. APLICAÇ̃̃O.

1. A natureza jurídica da remuneração dos serviços de água e esgoto, prestados por concessionária de serviço público, é de tarifa ou preço público, consubstanciando, assim, contraprestação de caráter não-tributário, razão pela qual não se subsume ao regime jurídico tributário estabelecido para as taxas (Precedentes do Supremo Tribunal Federal: $\mathbf{R E} 447.536$ ED, Rel. Ministro Carlos Velloso, Segunda Turma, julgado em 28.06.2005, DJ 26.08.2005; AI 516402 AgR, Rel. Ministro Gilmar Mendes, Segunda Turma, julgado em 30.09.2008, DJe-222 DIVULG 20.11.2008 PUBLIC 21.11.2008; e RE 544289 AgR, Rel. Ministro Ricardo Lewandowski, Primeira Turma, julgado em 26.05.2009, DJe-113 DIVULG 18.06.2009 PUBLIC 19.06.2009. Precedentes do Superior Tribunal de Justiça: EREsp690.609/RS, Rel. Ministra Eliana Calmon, Primeira Seção, julgado em 26.03.2008, DJe 07.04.2008; REsp 928.267/RS, Rel. Ministro Teori Albino Zavascki, Primeira Seção, julgado em 12.08.2009, 
DJe 21.08.2009; e EREsp 1.018.060/RS, Rel. Ministro Castro Meira, Primeira Seção, julgado em 09.09.2009, DJe 18.09.2009).

2. A execução fiscal constitui procedimento judicial satisfativo servil à cobrança da Dívida Ativa da Fazenda Pública, na qual se compreendem os créditos de natureza tributária e não tributária (artigos $1^{\circ}$ e $2^{o}$, da Lei 6.830/80).

3. Os créditos oriundos do inadimplemento de tarifa ou preço público integram a Dívida Ativa não tributária (artigo 39, $\$ 2^{\circ}$, da Lei 4.320/64), não lhes sendo aplicáveis as disposições constantes do Código Tributário Nacional, máxime por força do conceito de tributo previsto no artigo $3^{\circ}$, do CTN.

4. Consequentemente, o prazo prescricional da execução fiscal em que se pretende a cobrança de tarifa por prestação de serviços de água e esgoto rege-se pelo disposto no Código Civil, revelando-se inaplicável o Decreto 20.910/32, uma vez que: '... considerando que o critério a ser adotado, para efeito da prescrição, é o da natureza tarifária da prestação, é irrelevante a condição autárquica do concessionário do serviço público. O tratamento isonômico atribuído aos concessionários (pessoas de direito público ou de direito privado) tem por suporte, em tais casos, a idêntica natureza da exação de que são credores. Não há razão, portanto, para aplicar ao caso o art. $1^{\circ}$ do Decreto 20.910/32, norma que fixa prescrição em relação às dívidas das pessoas de direito público, não aos seus créditos.' (REsp 928.267/RS, Rel. Ministro Teori Albino Zavascki,Primeira Seção, julgado em 12.08.2009, DJe 21.08.2009)

5. O Código Civil de 1916 (Lei 3.071) preceituava que: Art. 177. As ações pessoais prescrevem, ordinariamente, em 20 (vinte) anos, as reais em 10 (dez), 
entre presentes, e entre ausentes, em 15 (quinze), contados da data em que poderiam ter sido propostas.

Art. 179. Os casos de prescrição não previstos neste Código serão regulados, quanto ao prazo, pelo art. 177."

6. O novel Código Civil (Lei 10.406/2002, cuja entrada em vigor se deu em 12.01.2003), por seu turno, determina que:

"Art. 205. A prescrição ocorre em dez anos, quando a lei não lhe haja fixado prazo menor.

(...)

Art. 2.028. Serão os da lei anterior os prazos, quando reduzidos por este Código, e se, na data de sua entrada em vigor, já houver transcorrido mais da metade do tempo estabelecido na lei revogada."

7. Consequentemente, é vintenário o prazo prescricional da pretensão executiva atinente à tarifa por prestação de serviços de água e esgoto, cujo vencimento, na data da entrada em vigor do Código Civil de 2002, era superior a dez anos. Ao revés, cuidar-se-á de prazo prescricional decenal.

8. In casu, os créditos considerados prescritos referem-se ao período de 1999 a dezembro de 2003, revelando-se decenal o prazo prescricional, razão pela qual merece reforma o acórdão regional. 
9. Recurso especial provido, determinando-se o retorno dos autos à origem, para prosseguimento da execução fiscal, uma vez decenal o prazo prescricional pertinente. Acórdão submetido ao regime do artigo 543-C, do CPC, e da Resolução STJ 08/2008.

Como se sabe, o STJ é o intérprete máximo da legislação federal, cabendo àquele Sodalício a uniformização da jurisprudência infraconstitucional. Cumpre destacar que tal decisão do STJ seguiu a linha doutrinária já consolidada pela STF, vejamos:

"EMBARGOS DE DECLARAÇÃO OPOSTOS À DECISÃO DO RELATOR: CONVERSÃO AGRAVO RM REGIMENTAL. CONSTITUCIONAL. TRIBUTÁRIO: TAXA DE ESGOTO SANITÁRIO. PRESTAÇÃO DE SERVIÇO POR CONCESSIONÁRIA. NATUREZA JURÍDICA DE PREÇO PÚBLICO.

(...)

II. - A jurisprudência do Supremo Tribunal Federal é no sentido de que não se trata de tributo, mas de preço público, a cobrança a título de água e esgoto. Precedentes.

III. - Embargos de declaração convertidos em agravo regimental. Nãoprovimento deste." (RE 447.536 ED, Rel. Ministro Carlos Velloso, Segunda Turma, julgado em 28.06.2005, DJ 26.08.2005)

"Agravo regimental em agravo de instrumento. 2. Água e esgoto. Cobrança. Natureza jurídica. Preço público. Precedente. 3. Prequestionamento. Ocorrência. 4. Agravo regimental a que se nega provimento." (AI 516402 AgR, Rel. Ministro 
Gilmar Mendes, Segunda Turma, julgado em 30.09.2008, DJe-222 DIVULG 20.11.2008 PUBLIC 21.11.2008)

"TRIBUTÁRIO. SERVIÇO DE COLETA OU TRATAMENTO DE ESGOTO. PREÇO PÚBLICO. CONSTITUCIONALIDADE. PREQUESTIONAMENTO.OCORRÊNCIA. I - Ocorrência do necessário prequestionamento, visto que a questão constitucional em debate foi devidamente discutida no acórdão recorrido. II - O quantitativo cobrado dos usuários das redes de água e esgoto é tido como preço público. Precedentes. III - Agravo regimental improvido." (RE 544289 AgR, Rel. Ministro Ricardo Lewandowski, Primeira Turma, julgado em 26.05.2009, DJe-113 DIVULG 18.06.2009 PUBLIC 19.06.2009)

"EMENTA: DIREITO TRIBUTÁRIO. COBRANÇA PELO SERVIÇO DE ESGOTO SANITÁRIO. NATUREZA JURÍDICA. TARIFA. ALEGAÇÃO DE INOBSERVÂNCIA DO PRINCÍPIO DA LEGALIDADE. OFENSA REFLEXA. SÚMULA STF 636. A cobrança pelos serviços de água e esgoto não consubstancia tributo. Trata-se de preço público. Precedentes. O exame da acenada violação do princípio da legalidade somente se viabilizaria com análise de âmbito infraconstitucional -inviável em sede de recurso extraordinário (Súmula 636/STF). Agravo regimental conhecido e não provido.” (AI 784175 AgR, Relator(a): Min. ROSA WEBER, Primeira Turma, julgado em 05/02/2013, ACÓRDÃO ELETRÔNICO DJe-037 DIVULG 25-02-2013 PUBLIC 26-022013)

"EMENTA: Agravo regimental nos embargos de declaração no recurso extraordinário. Constitucional. Serviços de água e esgoto. Natureza jurídica. 
Tarifa. Precedentes. 1. A jurisprudência desta Corte firmou-se no sentido de que o valor cobrado dos usuários pelos serviços de água e esgoto têm natureza jurídica de preço público, não de taxa. 2. Os fundamentos da agravante, insuficientes para modificar a decisão ora agravada, demonstram apenas inconformismo e resistência em pôr termo ao processo, em detrimento da eficiente prestação jurisdicional." (RE n 408.537-AgR, Relator o Ministro Cezar Peluso, DJ 6/3/08). 3. Agravo regimental não provido (RE 581085 ED-AgR, Relator(a): Min. DIAS TOFFOLI, Primeira Turma, julgado em 25/09/2012, ACÓRDÃO ELETRÔNICO DJe-201 DIVULG 11-10-2012 PUBLIC 15-102012)

“EMENTA: Agravo regimental no agravo regimental no recurso extraordinário. Inovação recursal. Impossibilidade. Serviços de esgoto. Natureza jurídica. Tarifa. Precedentes. 1. Não se admite, no agravo regimental, a inovação de fundamentos. 2. A jurisprudência da Corte firmou-se no sentido de que o valor cobrado dos usuários pelos serviços de esgoto tem natureza jurídica de preço público, não de taxa. 3. Agravo regimental não provido.” (RE 600237 AgR-AgR, Relator(a): Min. DIAS TOFFOLI, Segunda Turma, julgado em 17/03/2015, ACÓRDÃO ELETRÔNICO DJe-066 DIVULG 08-04-2015 PUBLIC 09-04-2015)

Não por outra razão, aliás, o Superior Tribunal de Justiça editou a Súmula 412 afirmando que "a ação de repetição de indébito de tarifas de água e esgoto sujeita-se ao prazo prescricional estabelecido no Código Civil'. Disso percebe-se que, se se tratasse de tributo, a prescrição seria regida pelo Código Tributário Nacional. Mencione-se, ainda, a Súmula 407 deste mesmo Tribunal Superior: “É legítima a cobrança da tarifa de água, fixada de acordo com as categorias de usuários e as faixas de consumo” 
Desta feita, conforme supramencionado, tanto o STJ quanto o STF entendem que o valor pago pelos serviços de água e esgoto prestados por concessionária de serviço público não possui caráter tributário, mas sim tem natureza jurídica de tarifa ou preço público, não se enquadrando, portanto, como arrecadação tributária apta a conformar a receita tributária prevista no Art. 29-A da CRFB.

Assim, se executado o serviço de água e esgoto pelo ente Municipal (diretamente ou de forma descentralizada, por intermédio de autarquia), os recursos serão contabilizados no Orçamento Fiscal, como sendo Receita de Serviços; já se houver a delegação do serviço para concessionária ou permissionária particular de serviço público, o valor decorrente dessa concessão pode ser registrado no Orçamento Fiscal em Receita Patrimonial.

\section{Referências Bibliográficas}

ATALIBA Geraldo. Regime constitucional e leis nacionais e federais. Revista de Direito Público. Ano XIII, nº 53-54, pp. 58-75, Jan./Jun. 1980.

BANDEIRA DE MELlo, Celso Antônio. Curso de Direito Administrativo. 31. ed. São Paulo: Malheiros, 2014.

CARVALHO, Paulo de Barros. Direito Tributário, linguagem e método. São Paulo: Noeses, 2009 - $3^{\mathrm{a}}$ edição.

ZOCKUN, Maurício Garcia Pallares. R. Proc.-Geral Mun. Belo Horizonte RPGMBH, Belo Horizonte, ano 3, n. 5, p. 249-260, jan./jun. 2010. 